\title{
Terbeschikkinggestelden tussen wal en schip
}

\author{
M.A.M. Wolters*
}

Toen mij ongeveer een half jaar geleden werd gevraagd een lezing te houden met als onderwerp "De geestelijk gestoorden tussen wal en schip", kon ik niet vermoeden dat het onderwerp vandaag zo actueel zou zijn, in het bijzonder voor de terbeschikkinggestelde geestelijk gestoorden. Het volgende is het geval.

Betrokkenen die een terbeschikkingstelling met dwangverpleging, door welke rechtbank dan ook, krijgen opgelegd worden geconfronteerd met wachttijden aan het begin van de tenuitvoerlegging van de opgelegde terbeschikkingstelling en met wachttijden in het eindstadium daarvan.

\section{Wachttijden aan het begin van de tenuitvoerlegging van een terbeschik- kingstelling}

Indien een terbeschikkinggestelde de combinatie van straf en maatregel krijgt opgelegd, zal na het passeren van de datum voor vervroegde invrijheidstelling (VI-datum) aansluitend de terbeschikkingstelling dienen te worden geëxecuteerd. De praktijk is echter dat een toenemend aantal terbeschikkinggestelden geruime tijd in een huis van bewaring de executie van de hun opgelegde maatregel moeten afwachten. Uit een vonnis van de rechtbank Den Haag van 1 maart 1995 maak ik op dat er op dat moment 70 zogenaamde TBS-passanten waren. Uit een vonnis van diezelfde rechtbank van 24 mei jl. maak ik op dat er op dat moment 80 TBS-passanten waren. Tijdens een kort geding dat ik op 4 oktober jl. voerde voor de president van de rechtbank Den Haag werd door de landsadvocaat meegedeeld dat er inmiddels 143(!) TBS-passanten waren en dat het aantal maandelijks snel toenam.

Niet alleen het aantal TBS-passanten vormt een probleem, maar vooral ook de passantentermijn. Deze termijn wordt steeds langer.

*Advocaat te Groningen. 
De gemiddelde wachttijd in een huis van bewaring, met al het gebrek aan faciliteiten van dien, heeft inmiddels de 12 maanden overschreden. Recentelijk vernam ik van een collega raadsman over een TBS-passant, die al 17 maanden na de VI-datum in een huis van bewaring verbleef. Zelf heb ik enkele zaken in behandeling waarbij de wachttijd is opgelopen tot respectievelijk 11, 12 en 13 maanden. Het moment komt snel dichterbij dat een verlengingsrechter geconfronteerd wordt met een verlengingsvordering terbeschikkingstelling, zonder dat de terbeschikkingstelling de eerste twee jaren tot een behandeling heeft geleid.

De wachttijd die een TBS-passant ondergaat is verdeeld in een wachttijd ter selectie en een wachttijd ter plaatsing. Het Dr F.S. Meijers Instituut te Utrecht, het instituut dat zorgdraagt voor de selectie, kent tegenwoordig wachttijden. Dit geldt eveneens voor alle TBS-klinieken in Nederland waar een terbeschikkinggestelde kan worden geplaatst.

De gebruikelijke rechtsbijstand bij wachttijden houdt in, dat ik de terbeschikkinggestelden na verloop van ca. 10 à 12 maanden adviseer een kort geding te starten. Het gaat daarbij om een kort geding tegen de Staat der Nederlanden, waarbij de president van de rechtbank, gewoonlijk de president in Den Haag, wordt verzocht een plaatsing te gebieden op straffe van onmiddellijke invrijheidstelling van de terbeschikkinggestelde. Tot op heden heeft de president van de rechtbank Den Haag een dergelijke vordering in kort geding afgewezen, waarbij de redenering van de president er op neerkomt dat de wachttijden weliswaar onwenselijk zijn, doch gezien de te verwachten capaciteitsuitbreiding vooralsnog acceptabel. Slechts de President van de rechtbank Maastricht heeft enkele maanden geleden een vergelijkbare vordering toegewezen. Van die uitspraak is de Landsadvocaat in hoger beroep gegaan.

In enkele recente uitspraken (bijv. in kort geding op 11 oktober jl.) heeft de Haagse president de suggestie gewekt dat een schadevergoeding aan wachtende terbeschikkinggestelden vanaf een zeker moment niet is uitgesloten. De president vond dat er maatschappelijk gezien sprake was van een zeer ernstige aangelegenheid. De civiele kamer van de rechtbank Den Haag heeft echter in een tweetal bodemprocedures, in welke schadevergoeding namens terbeschikkinggestelden werd verzocht, de schadevergoeding afgewezen. De civiele kamer maakte daarbij in haar uitspraak van 24 mei 1996 wel een kanttekening: " Niettemin merkt de Rechtbank op dat met een tijdsverloop van ongeveer 300 dagen de grenzen van het acceptabele in zicht zijn gekomen. Gedaagde (de Staat der Nederlanden) dient zich thans ernstig te bezinnen op alternatieven 
voor TBS-gestelden als eiser, zeker als wachtlijsten te vol raken. Dat in dit geval een, zij het niet optimaal, alternatief gevonden is in het Dr F.S. Meijers Instituut is een oplossing waarop gedaagde ook zonder kort geding en brieven van raadsvrouw van eiser wellicht eerder en uit eigen beweging had kunnen komen. De Rechtbank wenst hieraan toe te voegen dat niet uit te sluiten is dat in de naaste toekomst in dit soort gevallen, omdat gedaagde meer tijd gegund is alternatieven te vinden, anders zal worden beslist. Ook indien het tijdsverloop aanzienlijk korter zal zijn dan de ongeveer 10 maanden van dit geval". De voornoemde uitspraken hebben er toe geleid dat ik namens een drietal terbeschikkinggestelden inmiddels schadeclaims heb ingediend bij de Staat der Nederlanden. ${ }^{1}$ Eventueel zal ik in kort geding een voorschot vragen op een dergelijke schadevergoeding.

De vraag rijst hoe het komt, dat er op dit moment een zo grote groep wachtende terbeschikkinggestelden bestaat. Naar mijn mening dient de oorzaak te worden gezocht zowel aan de inputkant, als aan de outputkant van de terbeschikkingstelling. Er wordt de laatste 5 à 6 jaren vaker terbeschikkingstelling opgelegd dan daarvoor het geval was. ${ }^{2}$ Voorts behoort sinds een tweetal jaren een zogenaamde dwangobservatie tot de mogelijkheden, waarbij de verdachte in het strafproces dus niet meer de mogelijkheid heeft een observatie in een daarvoor bestemde kliniek, bijvoorbeeld het Pieter Baan Centrum, te weigeren (Wet van 15 december 1993, S. 1994, 13). ${ }^{3}$ Ook dat gegeven leidt tot meer terbeschikkingstellingen. Voorts is het zo dat na enkele vervelende incidenten rondom terbeschikkinggestelden, de rechtbanken en de penitentiaire kamer van het gerechtshof Arnhem minder geneigd zijn tot een zogenaamde contraire beëindiging van de terbeschikkingstelling. Dat wil zeggen een beëindiging van de terbeschikkingstelling tegen het advies van de kliniek in.

Samenvattend lijkt de maatregel terbeschikkingstelling langzaam maar zeker aan haar eigen succes ten onder te gaan.

${ }^{1}$ Noot van de redactie: In een van die procedures heeft de Haagse rechtbank op 24 juli 1996 uitspraak gedaan en een schadevergoeding toegekend aan een TBS-passant ad $f 50$,- per dag te rekenen vanaf de zevende maand en $f 100$,- per dag te rekenen van af de elfde maand van de wachttijd (rolnr. 96/696 VR).

2In 1994 zijn 187 terbeschikkingstellingen opgelegd tegen 74 in 1990; gegevens van het CBS in Criminaliteit en strafrechtspleging.

3Zie hierover de bijdragen van A.W.M. Mooij en L.C.M. Meijers in Ontmoetingen nr.1, november 1995. 


\section{Wachttijden in het eindstadium van de terbeschikkingstelling}

Voor een bepaalde categorie terbeschikkinggestelden, en dan in het bijzonder de groep psychotische terbeschikkinggestelden, hapert de gebruikelijke overgang van TBS-kliniek naar algemeen psychiatrisch ziekenhuis. Deze overgang vindt plaats in het kader van een TBS-proefverlof. Gelet op met name het beveiligingsrisico dat dergelijke terbeschikkinggestelden met zich mee zouden brengen, zijn algemeen psychiatrische ziekenhuizen niet erg genegen mee te werken aan een overplaatsing van dergelijke terbeschikkinggestelden in het kader van hun TBS-proefverlof naar een instelling van de algemene gezondheidszorg. Bovendien meent men dat het personeel onvoldoende is toegerust voor de begeleiding van mensen met een TBS-achtergrond. Hun overplaatsing wordt dan ook bij voortduring afgehouden. Ter illustratie wil ik een casus schetsen welke recentelijk werd behandeld door de rechtbank Dordrecht. De betrokken TBS-kliniek had reeds drie jaren geprobeerd de terbeschikkinggestelde geplaatst te krijgen in een algemeen psychiatrisch ziekenhuis. Het betrokken psychiatrisch ziekenhuis had bij voortduring, zelfs na een intakeopname, de boot afgehouden. Desalniettemin meende de betrokken TBSkliniek een plaatsing te moeten doorzetten. Telkens opnieuw werd de terbeschikkinggestelde aangemeld bij het algemeen psychiatrisch ziekenhuis, terwijl dat ziekenhuis op impliciete wijze de boot afhield. De rechtbank Dordrecht werd tijdens meerdere verlengingszittingen met het fenomeen geconfronteerd en besloot op 10 augustus jl. de zaak aan te houden met verwijzing naar art. 509t lid 2 van het Wetboek van Strafvordering. Dit bekent dat de Rechtbank overwoog de terbeschikkingstelling af te wijzen. De rechtbank verzocht de betrokken TBS-kliniek dringend naar alternatieven te zoeken voor een overplaatsing naar het aangezocht algemeen psychiatrisch ziekenhuis. De betrokken TBS-kliniek meende echter de aanmelding te moeten doorzetten en heeft daarmee de suggestie van de rechtbank genegeerd. Nu de rechtbank ook al tijdens eerdere verlengingszittingen terbeschikkingstelling alternatieven had gesuggereerd, was voor de rechtbank Dordrecht de maat vol. Bij beschikking van 2 november jl. werd de verlengingsvordering alsnog afgewezen. Ook de betrokken officier van justitie had de buik vol van de handelswijze van de betrokken inrichtingen en vorderde afwijzing van haar eigen verlengingsvordering. Een opmerkelijk detail in deze zaak betreft het volgende. Een dag na de verlengingszitting maakten beide inrichtingen kenbaar dat een overplaatsing inmiddels kon worden gerealiseerd. Voor de rechtbank (en de betrokken terbeschikkinggestelde) kwam een en ander echter te laat. Dit betekent dan ook dat een terbeschikkinggestelde, die in mijn visie niet buiten de hulp 
kon van een algemeen psychiatrisch ziekenhuis, vermoedelijk op straat terecht zou komen. Ik heb inmiddels de terbeschikkinggestelde kunnen motiveren op vrijwillige basis in het algemeen psychiatrisch ziekenhuis te verblijven. De vraag is echter: voor hoelang? 